\title{
TINJAUAN HUKUM EKONOMI ISLAM TERHADAP KEHIDUPAN POLIGAMI PADA KELUARGA MISKIN
}

\author{
Inna Fauziatal Ngazizah", Muhammad Zainal Abidin², \\ Lina Safitri ${ }^{3}$ \\ IAIN Kudus ${ }^{1}$, STAIT Yogyakarta ${ }^{2}$, UBSI Yogyakarta ${ }^{3}$ \\ Email:innafauzi@iainkudus.ac.id1 , Email:zabid27@gmail.com², \\ Email: linasafitri@bsi.ac.id ${ }^{3}$
}

\begin{abstract}
Life is a sure thing for every human being born into the world. Humans in their journey of life need many things to complete their lives and direction to help humans find the path of happiness in their lives. Humans are also social in nature, therefore humans need other humans to live side by side. Good life in small groups (families) is very influential in the lives of large groups (communities). Then the family life in this study is very important to study. This research focuses on the family life of polygamy which is known to cause problems. The focus of this study refers to the life of polygamy in poor families. The life of polygamy in four poor families is carried out in two different subdistricts located in Boyolali district, Central Java as an example of a real case that is happening in our community. This research is a field research using a sociological approach. The collection technique in this study uses interview techniques, documentation, with the Miles Hubberman analysis method, as well as using the economic theory of Maslow's hierarchy of needs. Research results show that the life of a polygamous family in a poor family is far from an ideal family and vulnerable to a family crisis. The ideal family who plays men as husbands who play a role as breadwinners, educators, set a good example and gives love and happiness to each individual. While the family crisis that occurs in the family life of polygamy is caused by the lack of basic religious, social, cultural and economic development that causes members in the family like this are far from good communication among fellow family members, egocentrism and problems that occur in every life of polygamy in poor families.
\end{abstract}

Keyword: Familiy, Polygamy, law, Ekonomic

\begin{abstract}
Abstrak
Kehidupan merupakan suatu hal yang pasti bagi setiap manusia yang terlahir kedunia. Manusia dalam perjalanan kehidupannya membutuhkan banyak hal untuk melengkapi hidupnya dan arahan untuk membantu manusia menemukan jalan kebahagiaan dalam hidupnya. Manusia juga bersifat sosial, maka dari itu manusia membutuhkan manusia yang lain untuk hidup secara berdampingan, Kehidupan yang baik dalam kelompok kecil (keluarga) sangat berpengaruh pada kehidupan kelompok yang besar (masyarakat). Maka kehidupan keluarga dalam penelitian ini sangat penting untuk dikaji. Penelitian ini memfokuskan pada kehidupan keluarga poligami yang diketahui menimbulkan persoalan. Fokus penelitian ini merujuk pada kehidupan poligami pada keluarga miskin dilihat
\end{abstract}


dari sudut pandang Hukum Ekonomi Islam. Kehidupan poligami pada empat keluarga miskin dilakukan di dua kecamatan yang berbeda yang terletak di Kabupaten Boyolali Jawa Tengah sebagai contoh kasus nyata yang tengah terjadi dimasyarakat kita. Penelitian ini adalah penelitian lapangan dengan menggunakan pendekatan sosiologis. Teknik pengumpulan dalam penelitian ini mengunakan Teknik wawancara, dokumentasi, dengan metode analisis Miles Hubberman, serta mengunakan teori ekonomi hirarki kebutuhan Maslow. Hasil penelitian menunjukan bahwa kehidupan keluarga poligami pada keluarga miskin jauh dari keluarga ideal dan rentan timbulnya krisis keluarga karena hukum ekonomi yang tidak relevan denan tujuan keluarga. Keluarga ideal yang memainkan laki-laki sebagai suami yang berperan sebagai pencari nafkah, pemberi pendidikan, menjadi teladan yang baik dan pemberi kasih sayang serta kebahagiaan bagi setiap individunya. Sedangakan krisis keluarga yang terjadi pada kehidupan keluarga poligami disebabkan oleh kurangnya dasar pembangunan agama, sosial, budaya dan ekonomi yang menyebabkan anggota yang terdapat dalam keluarga seperti ini jauh dari komunikasi yang baik diantara sesama anggota keluarga, sikap egosentrisme dan persoalan yang terjadi dalam setiap kehidupan poligami pada keluarga miskin.

Kata Kunci : Keluarga, Poligami, Hukum, Ekonomi

\section{PENDAHULUAN}

Poligami adalah bukan hal baru dalam kajian Islam, poligami sudah menjadi bagian dari diskursus pengkajian hukum keluarga sepanjang masa. Berbagai forum baik formal maupun non-formal. Jauh sebelum Islam diperkenalkan oleh Muhammad poligami sudah dipraktikkan oleh masyarakat Arab, bahkan dengan jumlah istri yang tidak dibatasi (Mulia, 2004: 345). Sejarah mencatat bahwa banyak tradisi agama yang sudah lama mengumandangkan isu-isu poligami. Agama Hindu menceritakan perkawinan dewa mereka yang memiliki ratusan istri (Shodiq, 2009: 32). Islam menganjurkan para muslim untuk menikahi para janda pada masa perang uhud.

Seiring perkembangannya poligami sedikit demi sedikit dibatasi jumlahnya. Sesuai dengan petunjuk kandungan surat an-Nisaayat 3, Nabi Muhammad melakukan perubahan secara radikal (Mulia, 2004: 39). Perubahan itu bertujuan untuk membatasi jumlah perempuan yang dapat diperistri oleh suami, yaitu dari tidak terbatas menjadi empat istri saja, dan menerapkan syarat yang ketat bagi pelaku yang hendak berpoligami. Pembatasan ini dikuatkan oleh Firman Allah di surat an-Nisa yang tertera dalam Al-Qur'an:

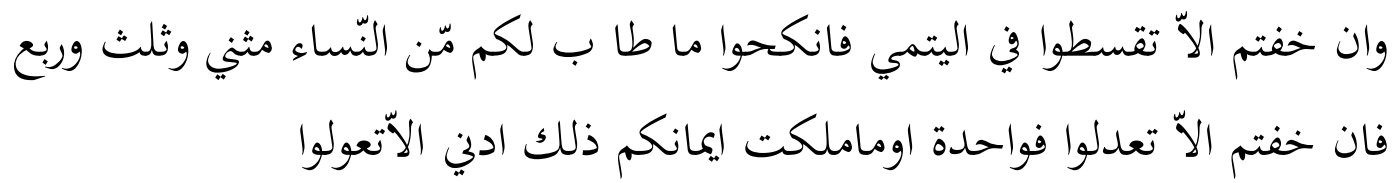


Tinjauan Hukum Ekonomi Islam Terhadap Kehidupan....

Artinya : "Dan jika kamu takut berbuat adil terhadap (hak-hak) perempuan yatim (bilamana kamu mengawininya), maka kawinilah wanita-wanita (lain) yang kamu senangi dua, tiga atau empat. Kemudian jika kamu takut untuk berbuat adil, maka kawinilah seorang saja, atau budakbudak yang kamu miliki. Yang demikianlah yang lebih dekat pada tidak berbuat aniaya".

Hadis yang diriwayatkan oleh Imam at-Tirmizi (Abu Isa Muhammad: Beirut) menyebutkan hal yang serupa:

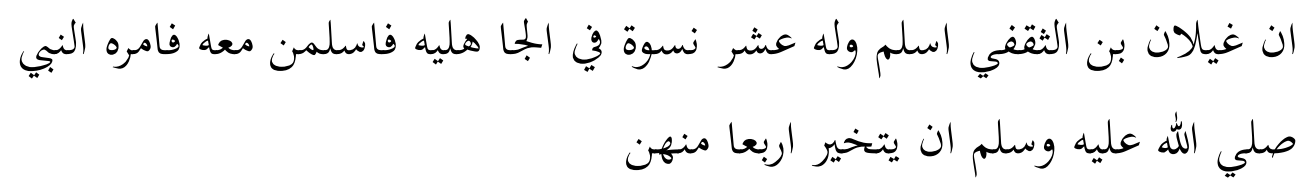

Artinya : "Dari Gailan bin Salah al-Saqafi yang masuk Islam tetapi dia memiliki sepuluh orang istri di masa jahiliyyah dan seluruh istrinya ikut masuk Islam bersamanya. Maka Rasulullah SAW memerintahkannya untuk memilih empat orang istri di antara mereka".

Hadis yang diriwayatkan oleh Abu Dawud:

$$
\text { وقال وهب اللهدي قال: اسلمت وعند ى ثما ن نسوة. فنكرت ذلك النبي صلى }
$$

Artinya : "Wahab bin al-Asadi berkata: aku masuk Islam dan aku punya delapan orang istri. Aku menuturkan hal itu kepada Rasulullah SAW Beliau bersabda: pilihlah empat orang istri di antara mereka".

Ayat tersebut ketentuan yang diterapkan di Indonesia. UndangUndang perkawinan Indonesia menyebutkan bahwa pengadilan hanya memberikan izin poligami kepada suami;(1) Istri tidak dapat menjalankan kewajibannya, (2) Istri memiliki cacat badan atau penyakit yang tidak dapat disembuhkan, dan (3) Istri tidak dapat melahirkan keturunan. Ketentuan-ketentuanmasih harus dibuktikan dan mencari jalan keluarnya terlebih dahulu secara sungguh-sungguh. Beberapa pandangan yang mengatakan bahwa alasan-alasan di atas bersifat diskriminatif dan memojokkan perempuan yang terpaksa memberikan izin poligami dan memaksanya untuk menerima kekurangan (Sulaiman, 1994: 986).

Ketentuan lain prasyarat poligami adalah Adanya persetujuan dari istri sebelumnya, adanya kepastian bahwa suami mampu menjamin hidup semua istri dan anaknya, dan menjamin bahwa suami akan berlaku adil terhadap istri-istri dan anak-anaknya.Jaminan kepastian berlaku adil dan mampu memenuhi kebutuhan para istri dan anak-anaknya oleh suami dalam berpoligami justru. Hal ini sejalan dengan firman Allah dalam surat an-Nisa ayat 129: 


\section{ولن تستطيعوا ان تعدلوا بين النساء ولو حرصتم فلا تميلوا كلّ الميل فتذروها كالمعلّقة}

Artinya : "Dan sekali-kali kamu tidak akan dapat berlaku adil diantara istriistrimu walaupun kamu sangat ingin melakukannya. Karena itu janganlah kamu terlalu cenderung kepada seseorang (istri yang kamu cintai) sehingga meninggalkan yang lain terkatung-katung..."

Penulis berpendapat bahwa definisi adil adalah sesuatu yang sangat sulit untuk didefinisikan dan tidak hanya sebatas $50 \%$ berbanding $50 \%$. Sedangkan definisi 'mampu' merupakan sikap relatif, yaitu definisi yang relatif bagi pelaku poligami dalam memberikan jaminan kehidupan dan realita pelaksanaan poligami. Realitas sosial menunjukkan adanya keluarga poligami dengan tingkat ekonomi rendah dalam memenuhi kebutuhan hidupnya serta keluarganya. Indeks kemiskinan dunia yang didasarkan pada bank dunia menunjukan bahwa seseorang dikatakan miskin jika memiliki pendapatan minimal Rp. 540.000,-/orang/bulan (Ali Khomsah: 2014). Suami sebagai kepala harus mempunyai standard tolok ukur pendapatan dalam memenuhi kebutuhan tiap anggota keluarganya. Data proverty line menurut bank dunia di atas menjadi rujukan dalam perekonomian keluarga, keluarga yang mempunyai pendapatan minimal atau di bawahnya akan mengalami banyak kesulitan dalam usaha untuk memenuhi kebutuhan hidupnya, terlebih hal itu jika terjadi pada keluarga poligami yang sangat rentan terjadi konflik internal antar anggotanya.

Realitas sosial menunjukkan bahwa ada beberapa keluarga poligami yang tingkat ekonominya rendah dengan jumlah istri lebih dari satu dan jumlah anak lebih dari dua (BKKBN). Contoh realita tersebut terjadi di daerah Boyolali kecamatan Karanggede dan Kecamatan Klego sedikitnya terdapat empat keluarga poligami dengan tingkat ekonomi rendah. Keluarga (a) memiliki dua istri dan sembilan anak dengan pekerjaan suami sebagai penjual ketupat tahu. Keluarga (b) memiliki dua istri dan tujuh orang anak dengan pekerjaan suami sebagai guru honorer. keluarga (c) memiliki dua istri dan lima orang anak kandung dan dua anak tiri dengan suami yang tidak memiliki pekerjaan. Keluarga (d) memiliki empat istri dan enam orang anak dengan pekerjaan sebagai tukang parker (Survey pertama).

Penulis menjadikan kasus di atas sebagai objek penelitian dalam tulisan ini dengan melihat kondisi kehidupan keluarga poligami dilihat dari segi maslahah yang menjadi tujuan pensyari'atan Islam serta melihat tujuan pernikahan dalam mewujudkan keluarga sakinah, mawadah dan rohmah. Kondisi ekonomi menurut Maslow keluarga sangat berperan penting dalam kelangsungan hidup. Kondisi ekonomi yang baik menjadikan manusia dapat memenuhi kebutuhan hidupnya. Penelitian ini menjadi menarik mengingat problem keluarga yang timbul akibat poligami selalu menarik untuk dibahas dan dikaji secara akademik untuk 
memperoleh solusi terbaiknya dalam mengurangi jumlah permasalahan keluarga poligami dan non poligami. Untuk memfokuskan analisa dalam penelitian ini. Penulis merumuskan permasalah sebagai berikut: bagaimana hak jaminan kehidupan anggota keluarga miskin pada perkawinan poligami? serta bagaimana kehidupan keluarga miskin yang tidak poligami?.

\section{METODE PENELITIAN}

Penelitian ini adalah penelitian lapangan (Field Research) dengan pendekatan kualitatif (Restu, 2010: 142). Keuntungan yang diperoleh dari jenis penelitian ini adalah peneliti dapat memperoleh informasi dan data sedekat mungkin dengan kenyataan di lapangan, sehingga data yang diperoleh dari informan atau responden lebih valid dan akurat.Penelitian ini dilakukan pada keluarga poligami di Kecamatan Karanggede dan Kecamatan Klego Kabupaten Boyolali.

Sumber data berasal dari data primer dan data sekunder. Data primer diperoleh melalui wawancara dengan para informan yaitu pelaku sebagai suami, pelaku sebagai istri, pelaku sebagai anak dan para tetangga yang mengenal dengan baik kondisi kehidupan keluarga poligami. Sedangkan data sekunder diperoleh dari artikel jurnal, buku-buku, dan lain sebagianya yang masih ada keterkaitan dengan judul penelitian ini. Uji keabsahan data dilakukan dengan teknik triangulasi data. Triangulasi yang dilakukan oleh penulis secara otomatis akan menguji kredibilitas data. Triangulasi dapat dibedakan menjadi empat macam, yaitu triangulasi sumber data, triangulasi pengamat, triangulasi teori dan triangulasi metode (Rahardjo, 2014: 89). Sedangkan tulisan ini menggunakan triangulasi metode.

Penelitian ini juga menggunakan pendekatan teori Miles dan Huberman untuk menganalisa data yaitu reduksi data, penyajian data dan penarikan kesimpulan atau verifikasi sebagai sesuatu yang saling menjalin pada saat sebelum, selama dan sesudah pengumpulan data dalam bentuk sejajar untuk membangun wawasan umum yang disebut analisis. Reduksi data diartikan sebagai pemilihan, pemusatan perhatian pada penyederhanaan, pengabstrakan, dan transformasi data "kasar" yang muncul dari catatan tertulis di lapangan. Pemilihan data "kasar" yang diperoleh dari hasil pengumpulan data. Penyajian data diartikan sebagai sekumpulan informasi tersusun yang memberi kemungkinan adanya penarikan kesimpulan dan pengambilan tindakan. Penarikan kesimpulan adalah tahapan terakhir dalam menganalisa data sebagai bagaian dari satu kegiatan konfigurasi yang utuh (Machael, 2014: 65). 


\section{PEMBAHASAN}

\section{Hak Jaminan Kehidupan Keluarga Poligami pada Keluarga Miskin}

1. Kehidupan Suami sebagai Pelaku Poligami Pada Keluarga Miskin

Suami adalah kepala rumah tangga yang dituntut secara sosial untuk mengemban segala bentuk kebutuhan kelangsungan setiap anggota keluarganya. Kebutuhan yang berupa kebahagiaan lahir maupun batin menjadi tanggung jawab suami bagi istri, dan ayah bagi anak-anaknya. Tanggung jawab dapat berupa jaminan kehidupan yang berlaku baik dalam perkawinan monogami maupun poligami. Perkawinan monogami suami dapat lebih fokus memberi hak jaminan kelangsungan hidup bagi istri dan anak-anaknya bila dibandingkan suami yang berada pada perkawinan jenis poligami.

Suami yang berada pada jenis perkawinan poligami beban tanggungjawabnya tentu lebih besar, baik bagi suami yang banyak memiliki pendapatan dalam kehidupannya maupun suami sedikit pendapatannya. Bagi suami yang memiliki banyak pendapatan dalam kehidupannya akan lebih mudah dalam membagi nafkah lahir kepada istri-istri beserta anak-anaknya. Tetapi bagi suami yang berpoligami dengan pendapatan yang minimum, dan terbatas hartanya, bisa dimungkinkan mengalami kesulitan dalam pembagian nafkah bagi istri-istri beserta anak-anaknya. Berikut adalah analisa kehidupan suami sebagai pelaku poligami pada keluarga miskin yang didasarkan pada penelitian yang peneliti berhasil temukan.

a. Suami pada Keluarga (a)

Suami pada keluarga (a) cukup memiliki tanggung jawab dalam menjamin hak-hak kehidupan bagi setiap anggotanya. Suami yang berprofesi sebagai penjual ketupat tahu di rumahnya memberikan keadilan bagi istri-istri beserta anak-anaknya. Keadilan bagi suami (a) adalah tidak cukup hanya sekedar 50\%-50\%. Namun, menurut suami (a) harus disesuaikan dengan porsi masing-masing. Hal ini terlihat dari cara suami dalam menafkahi para istrinya yangdidasarkan jumlah anak. Bagi istri yang mempunyai anak lebih banyak akan mendapatkan nafkah lahir lebih banyak dibandingkan dengan istri yang mempunyai anak lebih sedikit.

Suami (a) mendapatkan penghormatan dari istri-istri beserta anak-anaknya. Hal ini disebabkan suami mampu bersikap tegas dan adil dalam menempatkan setiap persoalan-persoalan rumah tangga yang berkaitan dengan lahiriyyah. Suami berhasil memberikan hak pendidikan bagi anak-anaknya dengan jenjang pendidikan yang sama rata yaitu tingkat SLTP. Suami juga menikahi kedua istrinya secara resmi baik menurut agama maupun menurut hukum perkawinan Indonesia. Namun suami (a) kurang memberi porsi 
yang adil dalam kebutuhan batiniyyah bagi kedua istrinya. Suami lebih condong memberikan nafkah batinnya kepada istri mudanya.

b. Suami pada Keluarga (b)

Suami (b) pada dasarnya memiliki kemampuan dalam menjamin kehidupan setiap anggotanya. Hal ini terbukti keberhasilannya memacu semangat akademik bagi anak-anaknya dari istri pertama untuk memperoleh beasiswa prestasi di bangku sekolah maupun di bangku kuliah. Semangat akademik yang memicu anak-anaknya untuk mendapatkan bantuan pendidikan dari berbagai lembaga yang menaungi pembiayaan pendidikan. Indikasi ini berasal dari latar belakang pendidikannya dan istri pertama yang mendapatkan pendidikan hingga jenjang strata 1 . Rumah tangga keluarga (b) mampu berjalan dengan baik dalam setiap lika-liku perjalanan kehidupannya. Akan tetapi permasalahan muncul ketika suami memutuskan untuk menikah lagi.

Suami pada keluarga (b) belum mampu membuktikan bahwa ia berhasil memberikan hak jaminan kehidupan secara menyeluruh kepada kedua istri beserta anak-anaknya. Hal ini terbukti dari nafkah lahir yang diberikan kepada kedua istri. Suami hingga kini hanya mampu memberikan hak tempat tinggal dengan bahan kayu blabak bagi istri keduanya. Suami (b) hingga kini berstatus nikah sirri dengan istri keduanya, pernikahan yang tidak dapat memberikan jaminan bagi kehidupan istri keduanya. Selain itu, suami mempunyai penyakit yang serius yang dapat menyebabkan berkurangnya kemampuan dalam menjamin hak-hak kehidupan kedua istri dan anak-anaknya.

c. Suami pada Keluarga (c)

Suami pada keluarga (c) tidak dapat memberikan hak jaminan bagi kehidupan bagi setiap anggota keluarganya. Hal ini terlihat dari tidak adanya rasa tanggung jawab dalam kehidupan istri pertama beserta anak-anaknya selama 20 tahun terakhir, ia tinggalkan dan ia abaikan tanggungjawabnya sebagai suami dan ayah bagi keempat orang anaknya. Istri pertama tidak diketahui secara jelas bagaimana status perkawinannya karena hingga ini suami (c) tidak menceraikan istri pertama secara hukum dengan alasan keterbatasan biaya.

Suami pada keluarga (c) saat ini juga tidak mampu memberikan hak jaminan kehidupan bagi istri kedua dan anaknya. Hal ini disebabkan karena suami menderita berbagai macam penyakit yang menderitanya. Kenyataan ini semakin memperjelas ketidakmampuannya dalam mencari nafkah lahir dan memberikan nafkah batin bagi istri keduanya. suami tidak mampu memberikan hak pendidikan bagi anaknya. Anak pada keluarga ini mendapatkan 
hak pendidikannya berupa beasiswa miskin yang statusnya merupakan bentuk perhatian dari masyarakat setempat. Suami (c) juga diindikasikan kurang memberikan kasihnya sebagai ayah bagi anaknya.

d. Suami pada Keluarga (d)

Suami pada keluarga (d) tidak memberikan hak jaminan kehidupan bagi istri-istri beserta anak-anaknya baik secara lahir maupun batin. Hal ini dapat dilihat dari tidak adanya tanggung jawab dalam kehidupan keluarga sebagai pencari nafkah lahir dan pemberi nafkah batin secara adil. Suami pada keluarga (d) tidak memberikan hak tempat tinggal bagi seluruh istrinya dan tidak memberikan hak nafkah lahir batin bagi seluruh istrinya. Hal ini terbukti dari penempatan seluruh istrinya dalam satu rumah yang merupakan hasil kerja keras dari istri kedua. Suami juga tidak mejamin hak kehidupan seluruh istri dengan menikahi istri kedua, istri ketiga, istri keempat dan istri kelimanya secara sah. Bahkan istri kelima mendapatkan perlakuan buruk yang berupa pencampakan dalam kehidupannya.

Suami juga tidak memberikan hak pendidikan bagi anakanaknya. seluruh biaya pendidikan anak-anaknya ditanggung oleh istri kedua yang merupakan ibu kandung mereka sendiri. Sedangkan anak kembar yang merupakan anak kandung dari istri kelima tidak ia pedulikan hak kehidupan, hak pendidikan dan hak kasih-sayang sebagai seorang ayah. Bahkan salah satu anak kembar tersebut dikabarkan telah meninggal dunia.

\section{Kehidupan Istri Pertama pada Keluarga Miskin}

a. Istri Pertama Pada Keluarga (a)

Istri pertama pada keluarga (a) cukup mendapatkan hak kehidupannya secara baik dalam kehidupan keluarga poligaminya. Ia juga mampu menjalin hubungan yang cukup baik dengan istri kedua dari suaminya maupun dengan anak-anak tirinya. Walaupun persoalan keluarga tidak dapat dihindari dari kehidupan keluarga baik keluarga monogami dan keluarga poligami. Namun, segala persoalan dapat terselesaikan dengan baik.

b. Istri Pertama pada Keluarga (b)

Istri pertama pada keluarga (b) sudah menjalin hubungan perkawinan monogami dengan suami selama 21 tahun dan mempunyai anak. Istri pertama dapat dikatakan hampir mampu berdiri sendiri dan tidak mengalami permasalahan keluarga yang begitu serius bagi kelangsungan kehidupannya maupun kehidupan anak-anaknya. Hal ini disebabkan dari penghasilan yang dapatkan secara mandiri melalui pekerjaannya sebagai guru honorer, anak- 
anak yang sudah menginjak usia dewasa, dan sedang menjalani pendidikan dengan biaya yang berasal dari beasiswa prestasi. Usia perkawinan yang sudah lama dijalani dengan suami tanpa adannya istri kedua banyak memberikan ketenangan lahir dan berpengaruh pada kondisi batin istri pertama pada keluarga (b).

Permasalahan muncul ketika istri pertama pada keluarga (b) harus menjalani kehidupan poligami dan berbagi suami dalam keterbatasan lahir maupun batin. Iamenderita penyakit jantung sehingga ia tidak bisa melayani dan menjalankan kewajibannya sebagai istri. Ia harus terpaksa merelakan untuk berbagi kasih dengan istri kedua dari suaminya. Akan tetapi, ia belum memberikan izin kepada suami untuk menikahi madunya secara resmi.

c. Istri Pertama pada Keluarga (c)

Istri pertama pada keluarga (c) tidak mendapatkan hak jaminan dari suami (c). Ia ditinggalkan tanpa tanggung jawab lahir maupun batin. Ia juga tidak mencari keberadaan suami pada keluarga (c) untuk menuntut haknya sebagai istri dan melakukan kewajibannya terhadap suami. Istri pada keluarga (c) bisa dikatakan telah terjadi putus hubungan (sebagai istri sang suami) karena hilangnya hak dan kewajibannya sebagai suami istri selama berpuluh-puluh tahun lamanya.

d. Istri Pertama pada Keluarga (d)

Istri pertama pada keluarga (d) diposisikan pada istri kedua. Hal ini disebabkan karena istri pertama yang sebenarnya pada keluarga ini sudah lama meninggal dunia. Istri kedua diposisikan istri pertama tidak mendapatkan hak jaminan kehidupan dalam keluarga poligaminya dengan layak. Ia tidak mendapatkan nafkah lahir dan tidak mendapatkan nafkah batin dari suaminya. Justru ia dapat dikatakan sebagai pemeran utama dalam keluarga.

Istri pertama dalam keluarga ini membiayai seluruh pendidikan kelima orang anaknya hingga jenjang pendidikan SLTP. Ia juga yang membangun tempat tinggal yang kini didiami oleh suami dan para istri mudanya. Ia juga pernah dituntut oleh suami untuk memberikan sebagian pendapatannya kepada suami (d). Bahkan sangat jarang sekali ia memperoleh hak giliran malam dalam keluarga poligaminya.

\section{Kehidupan Istri Kedua Pada Keluarga Miskin}

a. Kehidupan Istri Kedua pada Keluarga (a)

Kehidupan istri kedua pada keluarga (a) cukup mendapatkan keadilan dari suami dalam kehidupannya. Ia juga mampu membangun hubungan yang baik dengan istri kedua. Hal ini terlihat 
dari mereka yang saling peduli dengan pengasuhan cucu-cucu mereka. Ia mendapatkan perlakuan yang adil dari suami dalam pembagian nafkah lahir dengan istri pertamanya. Namun, ia mendapatkan nafkah yang lebih dari suami dalam hal kebatinan bila dibandingkan dengan istri pertama.

b. Kehidupan Istri Kedua Pada Keluarga (b)

Kehidupan istri kedua pada keluarga (b) memiliki rentang usia yang sangat jauh dengan suami dan istri pertama dari suaminya. Ia mempunyai usia yang hamper sama dengan anak pertama dari istri pertama suaminya. Hal ini menyebabkan dirinya kesulitan dalam beberapa hal seperti komunikasi yang kurang baik dengan istri pertama dan anak-anak tirinya. Ia masih membutuhkan waktu yang sangat lama untuk mendidik dan membesarkan anakanak kandungnya bila dibandingkan dengan istri pertama suami yang sudah memiliki anak-anak diusia remaja hingga dewasa.

Istri kedua memiliki pendidikan setingkat SLTP. Ia juga tidak mempunyai penghasilan secara mandiri dan hanya mengandalkan pemberian nafkah dari suami, padahal suami pada keluarga ini juga menderita penyakit ginjal yang mengharuskannya untuk mengganti darahnya setiap dua kali dalam seminggu. Hal itu lebih menyulitkannya untuk mendapatkan hak jaminan kehidupan bagi dirinya sendiri maupun bagi anak-anaknya yang masih sangat kecil (saat ini berusia 7 bulan dan 3 tahun).

c. Kehidupan Istri Kedua pada Keluarga (c)

Kehidupan istri kedua pada keluarga (c) tidak memiliki hak jaminan dari suami baik berupa nafkah lahir maupun nafkah batin. Hal ini disebabkan oleh terbatasnya kemampuan suami karena berbagai penyakit yang dideritanya. Penyakit yang membutuhkan biaya banyak dan perhatian yang sangat serius dari sekelilingnya karena kompilasipenyakit. Istri kedua pada keluarga ini yang pada akhirnya harus menerima segala macam beban rumah tangga. Ia berperan sebagai pencari nafkah keluarga. Berbagai macam jenis pekerjaan dilakukan untuk kelangsungan kehidupan keluarganya (tukang pijat panggilan, pengambil air bersih unntuk tetangga, penjaga lansia, mencuci, menyetrika, dan pekerjaan rumah lainnya). Selain ia harus menanggung biaya pengobatan suami, ia juga melengkapi kebutuhan kelangsungan pendidikan anaknya.

d. Kehidupan Istri Kedua pada Keluarga (d)

Kehidupan istri kedua pada keluarga (d) diposisikan oleh istri ketiga, istri keempat dan istri kelima dalam kehidupan poligami pada keluarga (d). Istri ketiga dan keempat mempunyai pekerjaan yang hampir sama, yaitu pekerja serabutan rumah tangga (mencuci, menyetrika dan pekerjaan rumah lainnya). Mereka diharuskan 
untuk mendapatkan penghasilan sendiri. Hal ini dikarenakan suami tidak memberikan nafkah lahir kepada mereka. Mereka juga tidak mendapatkan hak jaminan kehidupan resmi dari suami yaitu menikahinya secara sah menurut hukum perkawinan Indonesia. Mereka pernah mengalami tuntutan dari suami untuk memberikan penghasilan mereka kepadanya.

Istri ketiga dan istri keempat lebih mendapatkan nafkah batin dari sang suami bila dibandingkan dengan istri tertua dan istri termudanya. Hal ini disebabkan usia dan akal mereka yang masih bisa dikatakan normal. Istri tertua yang sudah tua dan istri termuda yang mempunyai gangguan jiwa. Gangguan jiwa dialami oleh istri kelima terjadi sudah sangat lama. Ia dicampakan dan tidak dipedulikan oleh suami. Ia juga tidak mendapatkan hak jaminan dengan dinikahi secara sah oleh suami seperti halnya istri ketiga dan istri keempatnya. Ia kini hidup bersama orang tua dan anak kembar yang salah satunya sudah meninggal dunia.

\section{Kehidupan Anak dari Istri Pertama}

Kehidupan anak dari istri pertama pada keluarga (a) mendapatkan hak jaminan kehidupan dari ayah mereka. Hal tersebut dapat terlihat dari keberhasilan mereka menyelesaikan jenjang pendidikan tingkat SLTP. Anak-anak pada keluarga (a) adalah berjumlah lima orang, kini seluruhnya sudah hidup berumah tangga dengan keluarga masing-masing. Mereka mampu hidup berdampingan dengan ibu tiri serta saudara-saudara tiri mereka.

Anak dari istri pertama pada keluarga (b) berjumlah lima orang. Mereka hampir seluruhnya mendapatkan hak-haknya sebagai anak dalam kehidupan keluarga poligami orang tua mereka. Mereka hingga saat ini seluruhnya berhasil mendapatkan beasiswa pendidikan prestasi yang sangat membantunya dalam keberlangsungan hidup masa depan mereka. Mereka juga dapat menghargai keputusan ayah mereka untuk berpoligami, walaupun diawal prosesnya sangat sulit bagi mereka. Mereka juga sudah menerima kehadiran ibu tiri mereka walaupun mereka menyebutnya dengan sebutan kakak. Kehidupan anak dari istri pertama pada keluarga (c) berjumlah empat orang. Mereka sama sekali tidak mendapatkan hak kehidupan dari ayah kandung mereka. Mereka sudah sangat lama ditinggalkan ayah mereka tanpa meninggalkan dan memberikan hak pendidikan, hak kasih sayang dan hak kehidupan dari ayah kandung mereka.

Kehidupan anak dari istri pertama pada keluarga (d) diposisikan pada anak istri kedua. Anak-anak dari istri pertama pada keluarga ini adalah berjumlah lima orang. Mereka mampu menyelesaikan pendidikan mereka hingga jenjang pendidikan SLTP dengan biaya dari 
ibu kandung mereka sendiri, yaitu istri pertama pada keluarga (d). Mereka kini sudah mampu mendapatkan pengahasilan secara mandiri dan mampu menghidupi kehidupan mereka sendiri. Namun, hal tersebut tidak serta merta berpengaruh dalam kehidupan keluarga poligami orang tuanya. Mereka belum bisa menerima sepenuhnya kehadiran ibu-ibu tiri mereka di rumah mereka.

\section{Kehidupan Anak dari Istri Kedua}

Kehidupan anak dari istri kedua pada keluarga (a) berjumlah empat orang anak. Mereka mendapatkan perlakuan yang sama dengan saudara-saudara tiri mereka. Mereka mendapatkan hak pendidikan hingga jenjang SLTP. Kehidupan anak dari istri kedua pada keluarga (b) adalah berjumlah dua orang. Usia mereka kini masih sangat kecil yaitu tujuh bulan dan tiga tahun. Hal ini menyebabkan mereka untukmendapatkan perhatian yang lebih dari orang tua mereka, terlebih dari ayahnya yang juga mempunyai anak-anak lain yang sudah remaja hingga dewasa dari ibu yang lain. Perjalanan hidup mereka masih sangat panjang. Namun, keberadaan mereka belum mendapatkan perhatian dari ibu tiri mereka, yaitu istri pertama dari ayah mereka. Walaupun saudara tiri mereka sudah mampu menerima kehadiran mereka, namun tidak bagi ibu tiri mereka yang hingga kini belum memberikan izin kepada ayah mereka untuk menikahi secara resmi ibu kandung mereka. Hal inilah yang menyebabkan status mereka sebagai anak kandung belum diakui sah oleh Negara.

Kehidupan anak dari istri kedua pada keluarga (c) adalah berjumlah tiga orang. Tetapi anak kandung dari suami (c) adalah anak terakhir yang kini menginjak usia lima belas tahun. Ia kini duduk di bangku sekolah tingkat SLTP dengan biaya yang berasal dari beasiswa miskin bantuan pemerintah. Ia sebenarnya kurang mendapatkan kasih sayang dari ayah. Ia sering mendapatkan perlakuan yang kurang baik dari sang ayah. Ia juga tidak tergolong siswa berprestasi di sekolahnya dan dalam catatan sejarah pendidikannya di Sekolah Dasar.

Kehidupan anak dari istri kedua pada keluarga (d) diposisikan pada anak dari istri kelima pada keluarga ini. Hal ini disebabkan karena istri ketiga dan istri keempat belum mendapatkan keturunan dari pernikahannya. Anak dari istri kelima pada keluarga (d) sebenarnya adalah anak kembar. Namun, salah satu dari mereka telah meninggal dunia. Hingga kini, ia tidak diketahui secara pasti keadaan kehidupannya karena ia juga tidak luput dari pencampakan sang ayah kandung. Pihak keluarga dari anak juga tidak menuntut tanggung jawab hak jaminan kehidupan. Jika ditelusuri secara usia anak maka kini ia menginjak usia anak sekolahan tingkat SLTP. 


\section{SIMPULAN}

Berdasarkan hasil pembahasan di atas, maka dapat ditarik konklusi diantaranya: 1) Hak jaminan kehidupan yang diberikan suami kepada setiap anggota keluarga miskin poligami kurang memenuhi kebutuhan hidup setiap anggota keluarga miskin poligami. 2) Hak jaminan kehidupan yang diperoleh istri pertama pada keluarga miskin poligami tidak memenuhi kebutuhan hidup lahiriyyah dan batiniyyah serta istri pertama merasa telah dirugikan psikologi dan materinya, 3) Banyak istri kedua keluarga poligami tidak terpenuhi hak jaminan kebutuhan hidupnya, baik secara nafkah lahir maupun batin. Hal ini mengharuskan mereka untuk bekerja secara mandiri untuk memperoleh pemenuhuhan kebutuhan hidupnya maupun keluarganya. 4) Terdapat kebutuhan hidup anak dari istri pertama keluarga miskin poligami yang tidak mendapatkan hak jaminan hidup dari ayah mereka setelah perkawinan poligami. 5) Kebutuhan hidup anak dari istri kedua tidak sepenuhnya mendapatkan hak jaminan hidup dan legalitas status anak yang sah secara hukum perkawinan Indonesia. Sehingga banyak hak-hak mereka yang terancam tidak terpenuhi dikemudian hari.

\section{SARAN}

Keluarga merupakan kelompok manusia yang sangat membutuhkan banyak hal untuk meraih tujuan dari terbentuknya keluarga tersebut. Selain itu juga penyelarasan antara tujuan pembentukan keluarga dan pembentukan tujuan hukum Islam juga sangat dibutuhkan agar saling bersinergi satu sama lain. Maka dari itu, penulis sekaligus sebagai peneliti fenomena sosial yang terjadi di masyarakat kaitannya dengan kehidupan poligami pada keluarga miskin memberi saran sebagai berikut:

a. Poligami bukanlah sesuatu untuk dinistakan akan tetapi laki-laki yang ingin berpoligami hendaknya tidak hanya mengikuti keinginannya untuk berpoligami saja, yang jauh lebih penting adalah baik buruknya kehidupan poligami setelah poligami itu terjadi. Dan perempuan yang menjadi faktor terjadinya poligami hendaknya memikirkan secara mendalam lagi bagaimana kehidupannya beserta perkembangan keturunannya yang tumbuh dalam kehidupan poligami terlebih dalam keluarga yang mempunyai keterbatasan pegetahuan agama, budaya dan ekonomi.

b. Pengetahuan mengenai pemahaman nafas-nafas agama hendaknya ditanamkan pada setiap individu dalam keluarga sedini mungkin. Banyaknya pengetahuan agama yang dimiliki jelas akan mempengaruhi pola dan tingkah laku seseorang dalam kehidupan sosialnya. 
c. Penanaman nilai budaya yang baik juga tidak kalah penting dalam kehidupan berkeluarga. Nilai budaya memberikan identitas pada diri sendiri yang berpengaruh sebagai kontrol sosial dan pembentuk prinsip kehidupan seseorang.

d. Pertimbangan ekonomi hendaknya sangat diperhatikan dalam keluarga sebagai salah satu unsur kesejahteraan kehidupan keluarga. Keuangan dan sumber-sumber yang dapat meningkatkan taraf hidup anggota keluarga merupakan cara yang akan meningkatkan taraf hidup keluarga. Ekonomi yang baik dalam keluarga tentu harus diimbangi dengan keadaan sosial keluarga.

e. Keadaan sosial dalam keluarga harusnya ditumbuhkan dengan baik oleh setiap anggotanya. Hal tersebut dapat dilihat dari hubungan yang baik dan benar-benar didasari ketulusan hati dan kasih sayang, saling menghormati, toleransi dan saling mempercayai. Hal-hal tersebut sangatlah penting dalam keluarga terlebih dalam kehidupan keluarga poligami pada keluarga miskin. Perwujudannya merupakan hal yang memang sulit dan sangat mustahil, namun bukan berarti tidak bisa terjadi.

\section{DAFTAR PUSTAKA}

Abu 'Isa Muhammad bin Isa bin Surah, al-Jami' as-Sahih (Sunan at-Tirmiz) (Beirut: Dar al-Fikr, t.t.), III: 435. Diriwayatkan pula oleh Ibn Majah, Ahmad bin Hibban, Syafi'i, Baihaqi dan menyatakannya sebagai hadis sahih.

Abu Dawud Sulaiman bin al-Asy'an As-Sijistani, Sunan Abu Dawud (Beirut: Dar al-Fikr, 1994), II: 248-249. Diriwayatkan pula oleh Ibnu Majah dan Baihaqi sekaligus menyatakannya sebagai hadis sahih.

Al-Qur'an Departemen Agama Republik Indonesia.

Hadi Sabari Yunus. Metodologi Penelitian Kontemporer. Yogyakarta: Pustaka Pelajar, 2010.

Moh, Sodik. Menyoal Keadilan dalam Poligami. Yogyakarta: Sukses Offset, 2009,

Musdah Mulia, Pandangan Islam tentang Poligami, Jakarta: Lembaga Kajaian Agama dan Gender bekerja sama dengan Perikatan Solidaritas Perserikatan Solidaritas Perempuan dan Thea Asian Foundation, 1999.

Mukhtar, Kamal, Asas-Asas Hukum Islam tentang Perkawinan, cet. ke-3, Jakarta: Bulan Bintang, 1993.

Mulia, Siti Musdah, Islam Menggugat Poligami, cet. Ke-1, Jakarta: Gramedia Pustaka Utama, 2004. 
Tinjauan Hukum Ekonomi Islam Terhadap Kehidupan....

Muslehudin, Muhammad, Filsafat hukum Islam dan Pemikiran Orientalis Studi Perbandingan Sistem Hukum Islam, dalam bab Al-Masalih alMursalah\} ataukepentingan tak terbatas, cet. Ke-2, Yogyakarta: Tiara Wacana Yogyakarta. 1997.

Nizar, Moh., Metodologi Penelitian. cet. Ke-7, Bogor: Ghalia Indonesia. 2013.

Restu Kartiko Widi, Asas Metodologi Penelitian Sebuah Pengenalan dan Penuntun Langkah demi Langkah Pelaksanaan Penelitian. Yogyakarta: Graha Ilmu, 2010.

Rosyidah Rachmawati, Wacana Poligami di Indonesia, editor Rochayah Machali (Bandung: Mizan Media Utama, 2005).

Sugioyo. Metode Penelitian Kuantitaf, Kualitatif dan RED. Bandung: Afabeta, 2011.

Widi, Restu Kartiko. Asas Metodologi Penelitian. Yogyakarta: Graha Ilmu, 2010. 
Inna Fauziatal Ngazizah, et al.

Halaman ini sengaja dikosongkan 